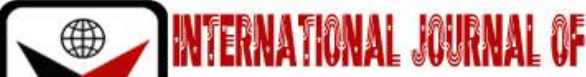

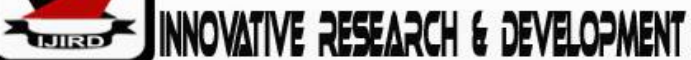

ISSN 2278-0211 (Online)

\section{Challenges Facing Unbanked Agribusiness Entrepreneurs towards Access to Bank Account}

\author{
Dr. Idris Yahaya Adamu \\ Lecturer, Department of Business Administration \\ Federal University of Kashere, Gombe, Nigeria
}

\begin{abstract}
:
This study explores the major challenges facing unbanked agribusiness entrepreneurs towards access to bank account savings and modern payment terminals, as an effort to increase their financial inclusion drive. The study used a phenomenological qualitative approach to explore the experiences of agribusiness entrepreneurs on financial inclusion issues. The study used the purposive sampling strategy in data collection through in-depth interviews. The study used Nvivo10 in the analyses and revealed that financial exclusion retards economic development through inaccessibility to financial services. The study also revealed that, despite visible effort in financial inclusion, some individuals are not accepting modern banking and payment services. Effort put by account officers to increase financial inclusion is not much as expected. Some individual entrepreneurs are found to be sceptical to using bank account and modern payment services. On the other hand, individuals face challenges of distance to service area, financial literacy and increasing charges for using payment terminals. These issues are impeding their access to financial services. The study increases entrepreneurs' awareness of financial services. Banks may use this study to predict clients' challenges and payments services. With this study, banks could also help financial regulators to redesign strategies towards modern payments and financial literacy.
\end{abstract}

Keywords: Access bank account, access to payments, financial exclusion, challenges facing unbanked and bank account officers' effort

\section{Introduction}

Nigerian government joined the alliance for financial inclusion since October 2008. The objective of national financial inclusion strategy (NFIS) was to ensure all Nigerian adults has access to affordable and convenient financial services by 2020, particularly access to banking services. Access to banking services refers to having at least savings account with deposit money (commercial) banks. The target of NFIS was to make sure at least 80 percent of Nigerian adults are having access to financial services by end of 2020. Despite the effort by NFIS, some Nigerian adults remain unbanked. However, unbanked Nigerian adults may be facing some challenges that hinder their access to banking services. This research paper is part of a larger data collection to identify success or otherwise of NFIS target among Nigeria adults by the end of 2020 .

Nigerian government through the central bank of Nigeria (CBN) spent a lot of money to ensure majority of adults (80\%) has access to banking, credit, insurance, pension and financial literacy. The success or otherwise of this strategy need to be assessed by the end of its target year. Over the years, rural entrepreneurs particularly those in agribusiness believed that banking services are for rich and people in the city. However, they make many financial transactions by cash transactions or by other means possible. Traditional agribusiness activities are largely seasonal and requires investing for at least five months to harvest their products, which requires money for this purposes. Therefore, there is need to identify how they save money, make payments and access credit facility.

\subsection{Problem statement}

Despite the availability of awareness facilities (communication infrastructure) for banking services, one may ask why some agribusiness entrepreneurs in rural areas remained unbanked. According to AFI Annual Reports, (2015), many individuals believed they don't have enough excess to save in bank. while others believe their savings is too small and for short time to take the pain of approaching bank.

People may consider amount they may spend on banking services as enormous, holding a bank account as unnecessary. However, they are ready to patronise banking agents for an emergency payments. Distance, inconveniences, and lack of financial education may be a contributing factor to non-patronage of banks (Albert, M., \& Kung'u, K. G., 2016).

Some individuals may open a bank account with a view of taking loans. But, due to stringent conditions associated with bank loans, they may not obtain the financing. Hence, they abandon the account, 


\subsection{Objective of the study}

In view of the above, the objective of this paper is to assess the success or otherwise of NFIS particularly to identify:

- The reasons why even at the end of year 2020, some individuals remained unbanked,

- The challenges unbanked are facing in their daily activities

- Effort of bankers towards mobilising unbanked to having bank account

- How unbanked individuals access savings, payments and credit services.

\section{Literature review}

Group of people vulnerable to exclusion may not be limited to extremely poor or disabled, even people in business may be in form of one exclusion or the other (Demirguc-Kunt \& Clappper, 2012). For instance, a well to do individual may voluntarily decide not to have a bank account or one may have bank account, accessing savings and payments, but may not be accessing credits, insurance, or pension despite the need to do so.

Researchers unanimously agree on the importance of increasing financial inclusion in an economy, Joshi \& Rajpurohit (2016), showed a direct relationship of banked individuals, households, or businesses and higher wealth networth. This is considerably due to a more likely for the banked people to financially plan for their future, have mortgages, and take advantage of their savings to hedge price increases. In another study, income, wealth, and education are found to be major determinants of financial inclusion (Dabla-Norris, Ji, Townsend, \& Unsal, 2015).

Even though, most of the excluded individuals are devising other means for savings like local saving thrifts and credits from family and friends, formal financial inclusion opens ways for further opportunities on investments, capital development, income, consumption smoothening and improving economic welfare (Brigit Helms, 2006). However, Financial inclusion drive has led to more inclusive growth, narrowed down income distribution gap and improved livelihood of households (OECD working paper, 2015). There is also a justified relationship of exclusion and drop in income, as evidenced from the studies of Dizon, Gong \& Jones, (2015), many banked individuals that stopped using their account (dormant account) and became unbanked was due to loss of job or sharp fall of income.

Concentration of financial infrastructure like bank branches and ATMs in urban areas is partly attributed to high rate of financial exclusion. Nigeria is like India with both voluntary and involuntary exclusion as situations warrant (Chowhan \& Pande, 2014), where as in china, financial exclusion is significantly voluntary, due to availability and easy access to formal financial services (Fungacova \& Weill, 2014).

Opinion differ on the supposed role of government in financial inclusion. Arun \& Kamath, (2015) believe that, government is responsible to provide direct involvement in the form of poverty alleviation programmes, grants, and interest-free loans, while others like Cull, Ehrbeck \& Holle, (2014), opined that it is enough for government to provide support and enabling policy environment to commercial financial institutions for inclusion to flourish. They suggested that success of financial inclusion requires reform minded government and effective financial institutions.

In the study of Naceur, Barajas, and Massara (2015), the number of excluded adults in northern Nigeria on the ground of religious reasons is relatively higher than other parts of the country, it was expected that Islamic finance can be a means for increasing inclusion. Their findings show that, despite growing physical access, use of financial services does not relatively increased as expected, they found evidence of link between credit usage to firms and household and the growing motivation to access financial services. A sound policy on financial education, consumer protection, financial and economic stability and a sound regulatory and supervisory framework may well be helpful in inspiring enterprises and households to use financial instruments. Thus, government as regulators need to support access and usage, more especially through financial institutions (Mohieldin, Mahmoud, Zamir Iqbal, Ahmed Rostom, and Xiaochen-Fu., 2011).

Even though the concept of Financial Freedom is missing while is needed to be included in financial literacy framework, because most financially intelligent people control expenses, saves, and invest their wealth, and makes plans for future and retirement (Lalrinmawia, and Gupta, 2015). Therefore, financial knowledge lead to positive behaviour on financial issues, which benefits the individual as well as a nation at large (Bank of Albania, 2011). Contrarily, in the absence of financial education, people are exposed to poor financial decision and planning, which leads to low living standard, decreased physical and psychological well-being and high rate of dependence on government's support for livelihood (Lusardi \& Mitchell, 2011).

Anjali-Kumar (2015) in her paper, access to financial services in Brazil, made a comprehensive assessment on financial inclusion programme, where she concludes that access for all is a collective responsibility and a big job to not only government and financial institutions but, an effort of many supporting institutions like communication sector. To ensure inclusive finance, Egbide, Samuel, Babajide \& Samuel, (2015) assert that it is a collective effort of regulators, financial and other supporting institutions to collectively eradicate exclusion.

The idea of microfinance is derived from the fact that, among the poor are those who want to access the necessary requirements to get out of poverty. Society need to ensure collective progress of all its members, and government is responsible for the welfare of its citizens; therefore, government must ensure undertaking all activities that are necessary for people to get small financing (Santosh, Subrahmanyam, \& Reddy, 2016). However, financial inclusion is unlike other social amenities like roads and buildings that can be set out indiscriminately, appropriate allocation is necessary. For any economy to progress, the overall standard of living must be improved, which requires massive employment of human, material, and intellectual resources of the nation. Employment of these resources requires entrepreneurship skills and funding for sustainable production of goods and services (Singh, 2015).

The most financially excluded class of entrepreneurs are found to be small-scale agribusiness sector entrepreneurs, this is largely due to their education level, distances to service providers, capital inadequacy and many 
other personal characteristics. Meanwhile, effort should be made by government, industry players, and financial service providers to explore the emerging opportunities for these entrepreneurs (Gonzalez, Diniz, \& Pozzebon, 2015).

Previous researchers like Santikian, (2014); Harisa, (2013) and Schaure \& Soden, (2011) has contributed in treating the issue of access to finance in conventional banking in relation to bank lending. While other researchers like Khalid \& Hanif, (2014); Masyita \& Ahmed, (2013) and Rehman, (2013) centered towards the banks' performance. Other researchers like Ahmed, Rehman \& Safwan, (2011) and Awan, Bukhari \& Iqbal, (2011) made an investigation on general financial inclusion, but they did not give much emphasis on excluded entrepreneurs.

\section{Research methodology}

The researcher used qualitative method of research because qualitative research method is used where researcher wants to understand the phenomena from the perspective of participants (unbanked agribusiness entrepreneurs) in rural areas and areas far away from cities (Creswell, 2013). Inductive research design is used as a better approach to generate an idea from data related to challenges facing unbanked entrepreneurs. Logical activities were made to connect data collected to the problem statement in order to generate a theory and formulate a relationship between variables (Creswell, 2013). The purposes of research are classified as; exploratory, explanatory, and descriptive (Marshall and Rossman, 1999) and (Wilkinson, 1991). Exploratory is the major intent (the purpose) of this study, because, it aims to explore participants' views with the intent of using these views to develop a theory. Inductive research is innately exploratory in nature (Creswell, 2013). Thus, this research is a qualitative method with exploratory purpose of identifying important issues in financial inclusion from multiple informants' perspective.

Data was collected through face to face interview with various small-scale agribusiness entrepreneurs. In-depth interviews intensively present respondents' feelings, emotions, and thoughts about the phenomena being researched (Easterberg, 2002). The researcher started by exploring the theoretical and conceptual revisions of the study area, where a gap is discovered from the current literature in respect to comprehensiveness of the previous studies. The researcher explored in depth the study, first from library research, then understanding the theoretical issues of the area, the researcher went in-depth to understand the practical background of the field from the CBN documents, other banks' archive, NFIS strategy documents, and other reports of private analyst. With determination to answer the research questions of this study, opinion of various small-scale agribusiness entrepreneurs was sought. On the process, small-scale agribusiness entrepreneurs were interviewed to understand the challenges they are facing on the process of being financially included.

After collecting all the relevant data discussed above, data management process was carried out by the researcher through collecting, preparing, and sorting the interview documents in form of notes, audio, and video records from the informants, and the data was transcribed and later coded for easy uploading on the Nvivo software and result's discussion. Population were small-scale agribusiness entrepreneurs as defined by SMEDAN Act, (2003), which are narrowed down to cultivation of rice and maize, irrigation, poultry, and processing in northern Nigeria. From the population, select sample informants with the said characteristics. Qualitative research experts did not make precise or definite number of participants as a sample, you have liberty for appropriate decision (Romeo 1989). Patton (1990) claims that there is no rule in qualitative research as par the range or number of participants that can be deemed appropriate. Likewise, Eisenhardt (1989) recommended that participants should be added to a point at which "theoretical dissemination" or "saturation" is attained.

Non-probability purposive sampling was used to select participants. Purposive sampling is appropriate when a researcher is selecting informants with some important features or characteristics, from extreme situations. It is better to purposively select informants that have knowledge of the population, elements, phenomena, and capable of providing information required (Marshall \& Rossman, 1999).

The researcher adopted and used eight principles of interview protocols from McNamara, Combell, \& Gilroy, (2004) to ensure researcher obtained what is supposed to be obtained, while observing research principles, ethics, and requirements for rigour. Data management processes were observed from beginning of the research to the end, to ensure trustworthiness, credibility and rigour

\subsection{Analysis of Findings}

Based on the data collection in way of interview, and in line with the literature review and methodology section of this study, the following findings were made.

\subsection{Peoples' Access to Bank Account}

Informants are categorised into two (2), those having bank account and those who do not have a bank account. Those who do not have a bank account were asked to express issues related to financial exclusion (bank exclusion) challenges. While, informants having bank account were asked to explain how frequent they use electronic payment channels to determine their extent of inclusion.

Unbanked in this research are agribusiness entrepreneurs excluded from having access to or use of an account in deposit money bank, including who indirectly use banking services through friends or relatives, provided they do not own a bank account. The six (6) excluded entrepreneurs were asked six (6) questions related to not having a bank account, to identify their exclusion challenges. Participants that have bank account, in this section are twelve (12) informants, and were asked how they use modern payment terminals. 


\subsection{Reasons for Not Having Bank Account}

All the six (6) unbanked agribusiness entrepreneurs were asked the reasons for not having a bank account. From their responses, two issues emerged, voluntary and involuntary reasons. The responses are shown in figure 1 below and discussed thereafter.

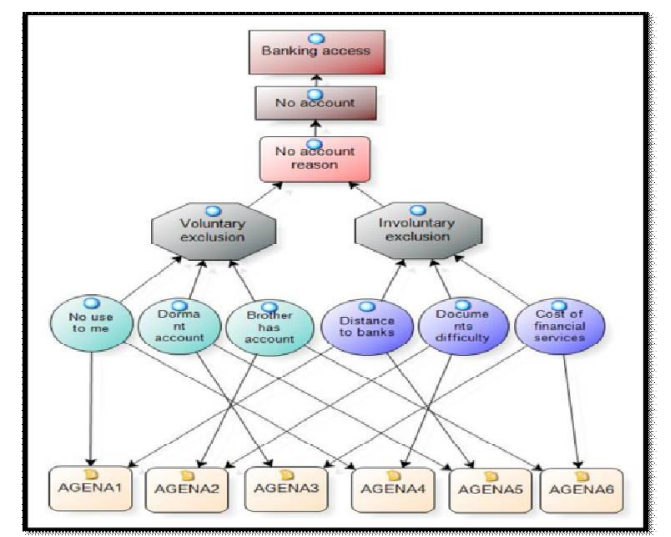

Figure 1: Excluded Entrepreneurs' Reasons for Not Having Bank Account

On the course of discussing with informants, researcher realised that some informants mentioned voluntary exclusion as a reason for not having bank account, such as those who says bank account is of no use to them, like the responses of AGENA1 and AGENA4, who show that, the account is of no use to them because they do not keep excess cash, they invest all their money in farming business. While other informants like AGENA 3 and AGENA 5 was having a bank account, but, no longer using it, the accounts are dormant. AGENA 5 added that he cannot be travelling for cash deposit or withdrawal, which unnecessarily take his time, so he stopped using the account. AGENA2 and AGENA6 are two informants mentioned that, their brothers have bank account, therefore, they don't need an account anymore. Access to banking services through another member of the family was the reason for not having account by.

While unbanked informants are stating their reasons for not having an account, researcher identified some involuntary reasons that contributes to not having a bank account. AGENA1 and AGENA5 are now excluded from banking services, due to transportation cost and other inconveniences associated with distance, because they live far away from bank. While other entrepreneurs like AGENA 2 and AGENA 4 realised that they do not have required documents to open account, like valid identification card and utility bill, where AGENA2 said that he doesn't have requirements for opening bank account, like valid means of identification card. AGENA 4 added that his friend told him that; he must produce some supporting documents that are difficult to get. Other two informants (AGENA3 and AGENA6) mentioned cost of financial services as their reasons for not having a bank account, where they indicate that, because account involves some expenses and transportation cost to and from bank, they can't afford to maintain a bank account.

\section{Major Challenges of Unbanked on Issues Related to Bank Account}

The next issue affecting unbanked entrepreneurs is to understand major challenges they have in relation to bank account issues. From their responses, three (3) sub-subthemes merged. Majority (AGENA 1,4, and 6) mentioned economic factors as their major challenge, while some entrepreneurs shows lack of confidence in financial institutions as a challenge, and cost of financial services as another challenge. The responses are shown in figure 2 below.

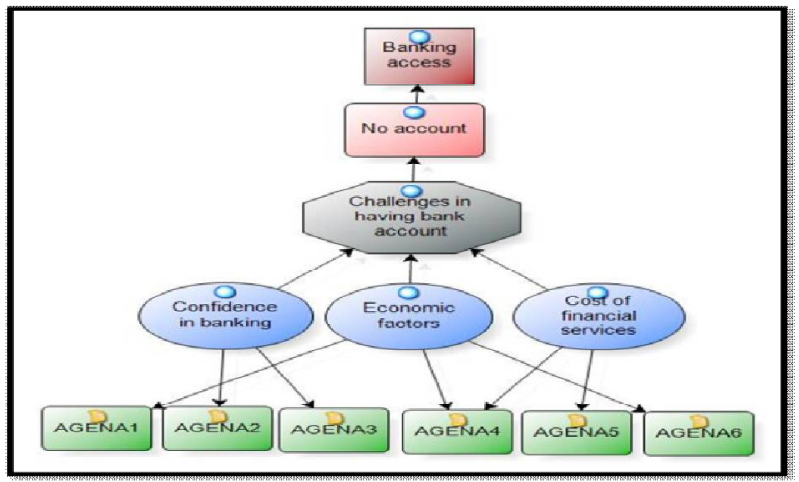

Figure 2: Major Challenges of Excluded Entrepreneurs

AGENA 2 and AGENA 3 shows lack confidence in government and financial sector, where AGENA2 said, government aid in the form of poverty alleviation funds don't reach small-scale farmers, which makes farmers to lose confidence in both the government and its institutions. While AGENA3 said he don't believe with the whole banking system, they can never help small-scale entrepreneurs, they either deceive customer to open account or exploit his money, or worst a customer falls in to the hands of fraudsters disguising as bankers or government agents to assist farmers. 
AGENA 1, 4 and 6 blamed economic factors as a challenge for not having bank account. AGENA1 blamed seasonal nature of his agricultural business, which makes his income and ability to save irregular, AGENA4 also said that, despite all their hard-work in farm, sometimes demand for farm output may be low, which affect their cash flow and income. While AGENA6 viewed his major challenge as prices instability, he said, the major challenge is fallen price of farm outputs and increasing cost of inputs, so, due to price changes, sometimes farmers are not making profit, even if they are lucky the harvest is good.

Cost of financial services is a challenge to AGENA4 and AGENA5, where they complained about cost of financial services as high compared to its benefits. This is shown in their response, where AGENA4 said, operating a bank account can cost him much money for all the documents they need and charges they make. While AGENA5 complained about distance and its related cost and inconveniences by looking at the distance of where they live, which is far away from bank branch. AGENA 5 added that, if for any demand of cash, they must cover a certain distance to main town, which make cost of banking too much to them.

\section{Account Officers' Effort on Outreach to Unbanked Entrepreneurs}

This question is aimed to identify whether entrepreneurs' lack of access to banking services is connected to bankers' marketing effort to invite small farmers for account opening or not. It is shown in figure 3 below that, only two entrepreneurs (AGENA3 and AGENA5) were ever contacted by bank staff, inviting them to operate a bank account.

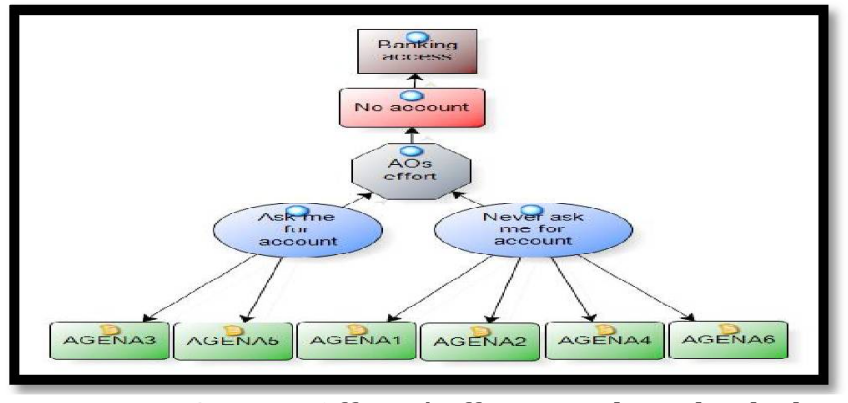

Figure 3: Account Officers' Effort to Make Unbanked Entrepreneurs Have Account

Only AGENA 3 and AGENA 5 responded that bank account officers ever asked them to open account. But, AGENA5 also added that bankers called him even recently to reactivate his dormant account, but he was not interested. This shows that banks are making little effort to reach unbanked agribusiness customers.

The remaining four farmers were never asked to open account, where AGENA1 said, he never sees any bank staff near his house or farm. AGENA2, AGENA4 and AGENA5 also said they never knew account officers on marketing mission.

\section{How Unbanked Saves Money, Makes Payments, and Access Credits}

Unbanked entrepreneurs were asked how they alternatively saves money, to know if small-agribusiness entrepreneurs are using another option like non-bank formal or informal way of saving money. Their responses were shown in figure 4 below, where majority are continuously reinvesting in their farming activities, not saving excess cash while others saves by themselves.

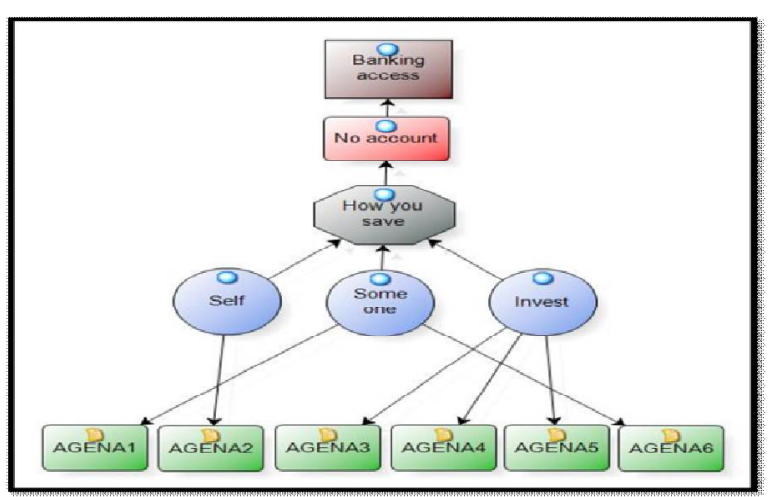

Figure 4: How Excluded Entrepreneurs Saves Money

Only AGENA2 said he is saving cash by himself at home, without the help of any other person or institution. AGENA1 said he is doing cooperative local savings trips (Adashe), where they contribute monthly, and give the monthly contribution to one person at a time. This way enables them to continuously raise capital for themselves. While AGENA6 have a trusted person that can keep cash for him.

The three (3) informants that always reinvest without keeping cash are AGENA3, 4 and 5. Where AGENA 3said, he buys some liquid non-perishable assets and keep, when he need cash, he can sell immediately, at profit. While AGENA4 says, he revolves all his money in farming and other local businesses. Lastly, AGENA5 also says he revolves funds in farming, local business, and as well keep liquid assets. 
At this era of modern payment systems, the researcher became anxious to know, without a bank account, how an entrepreneur can make or receive payments to and from other parties. The entrepreneurs gave their idea of how to send money to or receive from another person. The pattern of their responses is shown in figure 5 below.

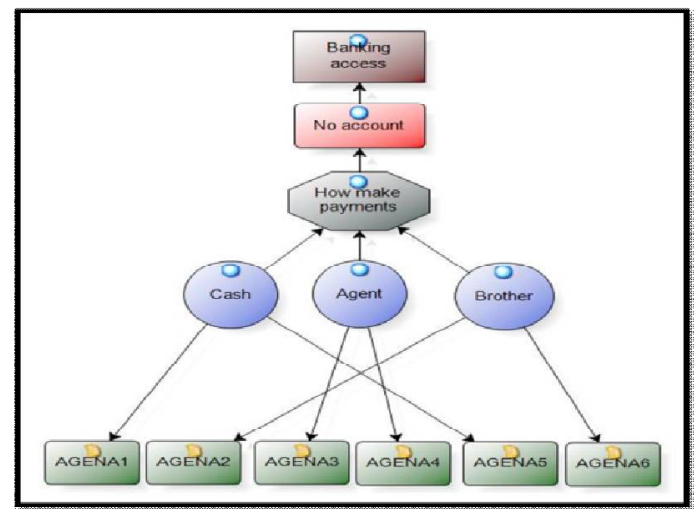

Figure 5: How Excluded Entrepreneurs Makes Payments

AGENA1 and AGENA5 responded that, they only relay on making and receiving payments on cash basis. Because, all their business partners and markets are completely cash oriented. AGENA2 and AGENA6 responded that though they use cash basis, but, when necessary, they can call their brothers who operate a bank account to do that for them. While AGENA3 and AGENA4 in the other hand said that, they do transactions on cash basis. But, if it became necessary, they either go and make a cash deposit to receiver's account or get someone else to do whatever is needed for them, for a little reward.

The researcher asked unbanked entrepreneurs, how do they get money, if they need additional funding? There responses show that majority (AGENA 4, 5 and 6) relies on buying goods on credits from local traders or taking cash advance from buyers of their farm product, as a way of raising additional funds (trade credit), while other farmers relays on family and friends or sale their assets to raise cash. The responses are shown below in figure 6.

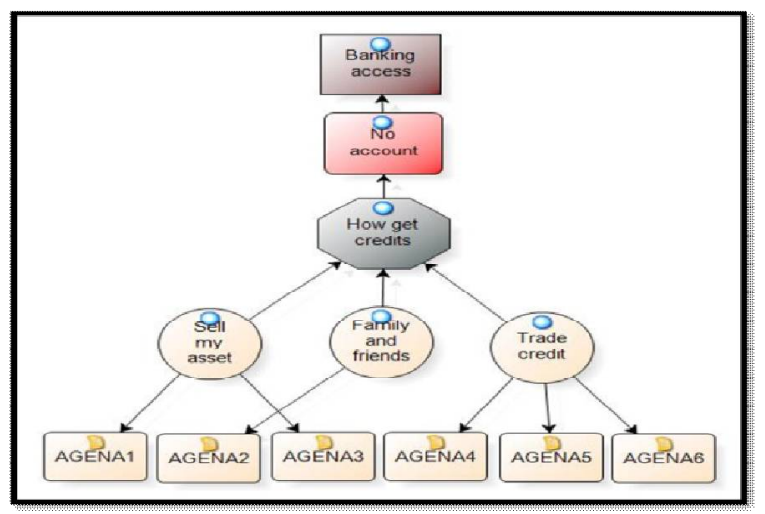

Figure 6: How Excluded Entrepreneurs Access Credits

AGENA2 mentioned friends and relatives as a source of benevolent loans. He shows that, when he is in need, a family member or a friend can give him to an appointed time. But, AGENA1 and AGENA3 indicates that, they don't want to take loans from anyone, rather, they prefer to use personal funds from their savings or sell any of their liquid asset to raise money. The impression they give is, they are doing farm business within their resources, they do not require additional funding. While AGENA4, AGENA5, and AGENA6, prefer making credit purchases from local vendors and some-times collect cash advance from their business associates (buyers) for sale of their farm produce, to raise money.

Above five responses came from unbanked entrepreneurs to understand their issues related to bank account access.

\section{Discussion of findings}

Some unbanked entrepreneurs willingly refused to have access to financial services (voluntary exclusion), and among them are those who has access to financial services through their family members, friends, or agents. Therefore, involuntary exclusion among entrepreneurs is minimal, particularly among those living not far away from banks. The reason for voluntary exclusion was largely due to cost associated with access to banking services, compared to its benefits. In some other cases, agribusiness entrepreneur may be qualified to be included by all ramifications, but, can deliberately ignore formal financial services largely because all their business transactions are cash-based. Therefore, they voluntarily refuse formal financial services because they do not need banking services.

Distance between farm-lands or household of some agribusiness entrepreneurs to access points of banking services does not significantly influence access to financial services of the entrepreneurs. This is evidenced by some entrepreneurs (AGENA 2, 3, and 6) who are living not far away from banking service points, yet, they do not operate bank account. In the other hand, despite long distance of some entrepreneurs (AGEA 2 and AGEAC1), they operate a bank 
account and using various banking products and channels. This finding on agribusiness entrepreneurs contradicts the finding of EFInA survey, (2014), which indicates effect of household's distance of farmers to banking service points (rural $25 \%$, urban $56.3 \%$ banked adults). The qualifying factor is, EFInA survey, (2014) consider all adults living in rural area, including all subsistence farmers, while this study surveys only agribusiness entrepreneurs. This shows that level of education, farm size and volume of business activities plays a greater role than distance in willingness to access banking services.

Like in some previous studies which indicate that; challenges of financial exclusion are not only a function of illiteracy, but also due to challenges of lack of trust in financial sector, income (irregular income or no job), physical access (too far away from financial services or high transportation cost), affordability (financial services are expensive to have) as well as eligibility to documentation process (Dabla-Norris, et. el., 2015). This study also shows the challenges of physical access and documentation, where some unbanked entrepreneurs mentioned physical access, affordability, and documentation challenges as their reasons for not having a bank account.

Another challenge is that excluded rural based agribusiness entrepreneurs does not know or ignore the role of financial institutions in increasing inclusion. On the process of discussion, some unbanked entrepreneurs insisted on government direct intervention (aid) like poverty eradication programme as the only way of increasing their inclusion. This is deduced from the responses of AGENA4 and AGENA6. These challenges are shown in figure 7 below.

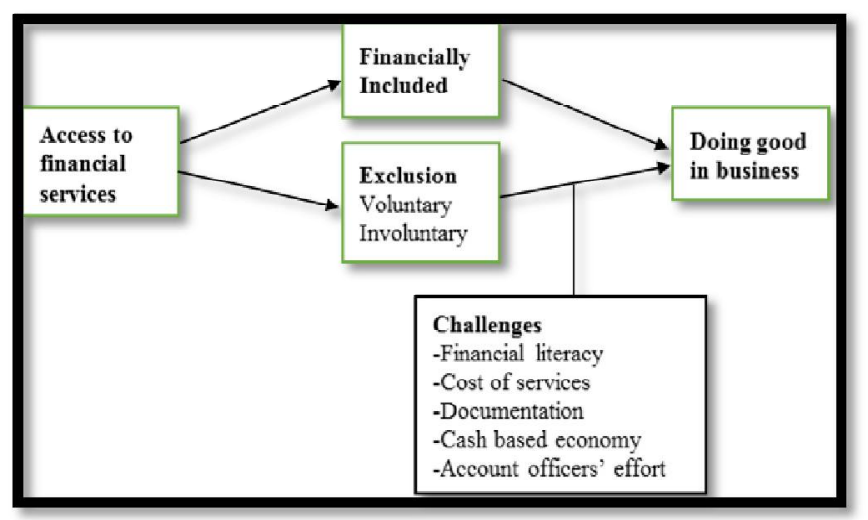

Figure 7: Challenges of Unbanked Entrepreneurs towards Access to Financial Services

The challenges above may be connected to poor account officers' effort to reach farmers. This is justified by the responses of majority (4) of unbanked entrepreneurs who affirm that they never see any bank staff requesting them to open bank account. Lack of bank account necessitated unbanked entrepreneurs to use traditional mode of savings, payments, and credit access.

\section{References}

i. AFI Annual Reports, (2015). Reports of the Alliance for financial inclusion. Available at https://www.afiglobal.org/publications/2141/2015-AFI-Annual-Reports Aga, G. A.,

ii. Ahmad, A., Rehman, K. U., Saif, M. I., \& Safwan, M. N. (2011). An empirical investigation of Islamic banking in Pakistan based on perception of service quality. African Journal of Business Management, 4(6), 1185-1193.

iii. Albert, M., \& Kung'u, K. G. (2016). Agency Banking and Accessibility to Financial Services: A Survey of Commercial Banks in the Northern Province of Rwanda. International Journal of Innovative Research and Development, 7(7). Demirguc-Kunt \& Clappper, 2012).

iv. Allen, F., Demirguc-Kunt, A., Klapper, L., \& Peria, S. M. (2016). Foundations of Financial Inclusion. World Bank Policy Research Working Paper.

v. Arun, T., \& Kamath, R. (2015). Financial inclusion: Policies and practices. IIMB Management Review, 27(4), 267287.

vi. Awan, H. M., Bukhari, S. K., \& Iqbal, A. (2011). Service quality and customer satisfaction in the banking sector: a comparative study of conventional and Islamic banks in Pakistan. Journal of Islamic Marketing, 2(3), $203-224$.

vii. Chowhan, S. S., \& Pande, J. C. (2014). Pradhan Mantri Jan Dhan Yojana: A giant leap towards financial inclusion. International Journal of Research in Management \& Business Studies, 1(4), 19-22.

viii. Creswell, J. W. (2012). Educational research: Planning, conducting, and evaluating quantitative. 4th ed. Pearson.

ix. Creswell, J. W. (2013) Qualitative Inquiry and Research Design: Choosing among Five Approaches, 3rd edition, Thousand Oaks, CA: Sage.

X. Cull, R., Ehrbeck, T., \& Holle, N., (2014). Financial Inclusion and Development: Recent Impact Evidence. Focus Note, 92.

xi. Dabla-Norris, E., Deng, Y., Ivanova, A., Karpowicz, M. I., Unsal, D. F., vanleemput, E., \& Wong, J. (2015). Financial Inclusion: Zooming in on Latin America (No. 15-206). International Monetary Fund.

xii. Dabla-Norris, E., Ji, Y., Townsend, R. M., \& Unsal, D. F. (2015). Distinguishing Constraints on Financial Inclusion and Their Impact on GDP, TFP, and Inequality (No. w20821). National Bureau of Economic Research. 
xiii. Egbide, B. C., Samuel, F., Babajide, O., \& Samuel, F. (2015). What financial inclusion in Nigeria should include. American Journal of Scientific Advances, 1(1), 36-42.

xiv. Eisenhardt, K. M. (1989). Building theories from case study research. Academy of management review, 14(4), 532-550.

xv. Gonzalez, L., Diniz, E. H., \& Pozzebon, M. (2015). The Value of Proximity Finance: How the Traditional Banking System Can Contribute to Micro-finance. innovations, 10(1-2), $\quad$ 125-137.

xvi. Joshi, M., \& Rajpurohit, V. (2016). Awareness of Financial Inclusion: An Empirical Study.

xvii. Khalid, M. B., \& Hanif, M. (2014). Comparative Risk Return Analysis of Conventional and Islamic Banks in Pakistan. Available at SSRN 2419326.

xviii. Lalrinmawia, M., \& Gupta, H. (2015). Literacy and Knowledge: Farmers' Financial Inclusion Feasibility. SCMS Journal of Indian Management, 12(3), 17.

xix. Lusardi, A., \& Mitchell, O. S. (2011). Financial literacy around the world: an overview. Journal ofPension Economics \& Finance, 10(4), 497-508.

xx. Marshal, C., \& Rossman, G. B. (1999). Designing qualitative research (3rd ed.). Thousand OIaks, CA: Sage.

xxi. McNamara, O., Combell, A., \& Gilroy, P. (2004). Practitioner research and professional development in field of education. England: Paul Chapman Publishing

xxii. Mohieldin, Mahmoud, Zamir Iqbal, Ahmed Rostom, and Xiaochen-Fu., 2011).

xxiii. Ben Naceur, S., Barajas, A., \& Massara, A. (2015). Can Islamic Banking Increase Financial Inclusion? IMF working paper WP/15/31

xxiv. OECD (Organisation for Economic Co-operation and Development). (2015). Innovation and knowledge-intensive service activities. Paris, OECD Publishing.

xxv. Pattton, M. Q. (1990), Qualitative evaluation methods, Sage Publications, Beverly Hills, CA.

xxvi. Santikian, L. (2014). The ties that bind: Bank relationships and small business lending. Journal of Financial Intermediation, 23(2), 177-213.

xxvii. Santosh, K., Subrahmanyam, S. E. V., \& Reddy, T. N. (2016). Microfinance; A holistic approach towards Financial Inclusion. Imperial Journal of Interdisciplinary Research, 2(9).

xxviii. Singh, (2015). Role of Public Sector Banks in Financial Inclusion. Global Journal of Multidisciplinary Studies, 4(6).

xxix. Wilkinson, A.M. (1991). The scientist's handbook for writing papers and dissertations. Englewood Cliffs, NJ: Prentice Hill, 